\title{
Disease Control Attributes of Oxathiapiprolin Fungicides for Management of Cucurbit Downy Mildew
}

\author{
Sarah E. Salas, ${ }^{1}$ Christopher P. Shepherd, ${ }^{1}$ Henry K. Ngugi, ${ }^{1}$ and Jean-Luc Genet ${ }^{2, \dagger}$ \\ ${ }^{1}$ DuPont Crop Protection, Stine-Haskell Research Center, Newark, DE 19711, U.S.A. \\ ${ }^{2}$ DuPont de Nemours (France), 68700 Cernay, France
}

Abstract

\begin{abstract}
Oxathiapiprolin, a novel oomycete fungicide recently registered by DuPont, was reported to have high intrinsic activity against cucurbit downy mildew (Pseudoperonospora cubensis). The goal of this study was to characterize disease control attributes of oxathiapiprolinbased fungicides critical to effective management of cucurbit downy mildew. In growth chamber and greenhouse studies, oxathiapiprolinbased fungicides were compared with mandipropamid, mefenoxam + mancozeb, fluopicolide + propamocarb, cymoxanil + mancozeb, and ametoctradin + dimethomorph products for pre- and postinfection activity, local systemic movement, and protection of new growth produced after fungicide application. In preventive application, oxathiapiprolin-based fungicides significantly $(P<0.0001)$ inhibited downy mildew development, with the highest level of disease observed being $0.4 \%$ compared with $86.7 \%$ observed for mandipropamid. When applied postinfection, oxathiapiprolin-based fungicides significantly $(P<0.0001)$ suppressed disease development, but disease control was reduced relative to that observed for preventive application. There was a significant effect of formulation on the postinfection activity of
\end{abstract}

oxathiapiprolin, whereby the oil dispersion (OD) formulation was more inhibitory than the water-dispersible granule formulation $(0.001$ $\leq P \leq 0.049$ ). Disease severity on the outer half leaf portion protected from spray deposition during fungicide application was lower for oxathiapiprolin-based fungicides (1.6 to $6.6 \%$ ) than observed for fluopicolide + propamocarb (10.9 to $23.7 \%$ ), mefenoxam + mancozeb (40.3 to $51.4 \%$ ), and the nontreated controls ( 83.3 to $84.9 \%$ ), which indicates significant acropetal movement within the leaf. Postinfection applications of oxathiapiprolin-based formulations had the greatest effect on lesion growth and sporangia production compared with the other fungicides in the experiment. When applied preventively to rapidly growing plants in a greenhouse, oxathiapiprolin-based fungicides consistently protected new growth that was not present at the time of application, with the OD formulation reducing disease severity by $>75 \%$ relative to nontreated plants. The practical implications of these observations are discussed.

Keywords: cucumber, Pseudoperonospora cubensis, downy mildew, oxathiapiprolin
Cucurbit downy mildew caused by the oomycete Pseudoperonospora cubensis (Berk. \& M. A. Curtis) Rostovzev is one of the most damaging diseases of cucurbitaceous crops worldwide (Palti and Cohen 1980; Thomas 1996). All cucurbit crops can suffer total loss when downy mildew infections occur early in the crop season and fungicides are not used. Although the preventative use of fungicides generally provides adequate disease control, applications made 1 week after symptom appearance can result in a yield reduction of approximately 50\% (Holmes et al. 2015). The pathogen overwinters on wild or cultivated cucurbits in areas without severe frost such as Florida in the southeastern United States. In temperate zones, the pathogen may overwinter on plants in heated greenhouses. Sporangia produced on overwintered plants are the source of primary inoculum and can be dispersed by wind currents over short or long distances (Ojiambo and Holmes 2011). Airborne sporangia that land on a susceptible host can germinate in the presence of wetness to release 5 to 15 zoospores per sporangium. Depending on temperature, about $2 \mathrm{~h}$ of leaf wetness is required for the early stages of the infection process (Neufeld and Ojiambo 2012; Thomas 1996). The infection process entails zoospores swimming to locate stomata, where they encyst before forming a germ tube and an appressorium for penetration of host tissue (Palti and Cohen 1980; Savory et al. 2011; Thomas 1996).

Traditionally, cucumber downy mildew was managed by an integrated approach that combined planting of resistant cultivars, cultural practices that reduce leaf wetness, and a timely but limited

${ }^{\dagger}$ Corresponding author: J.-L. Genet; jean-luc.genet@dupont.com

The author(s) declare no conflict of interest.

Accepted for publication 23 May 2019.

() 2019 The American Phytopathological Society application of broad-spectrum protectant or oomycete-specific fungicides (Holmes et al. 2006). However, changes in P. cubensis population structure over the last two decades have resulted in a prevalence of highly virulent strains in all major cucurbit production regions (Cohen et al. 2003, 2015; Holmes et al. 2006; Lebeda and Urban 2007). The prevalence of virulent strains combined with limited availability of short-lasting resistant cultivars has made chemical control critical to commercial cucumber production (Call et al. 2012; Cespedes-Sanchez et al. 2015). For example, in the United States, fungicides are applied as often as every 5 to 7 days on cucumber (Cespedes-Sanchez et al. 2015; Neufeld and Ojiambo 2012; Savory et al. 2011), and as many as 11 applications may be required to fully protect the yield of field-grown cucumbers when downy mildew occurs early in the cropping season (Ojiambo et al. 2010).

Chemical control of cucumber downy mildew, while effective, has its challenges, among which is the rapid selection of $P$. cubensis populations with resistance to site-specific fungicides. The Fungicide Resistance Action Committee (FRAC) considers P. cubensis a pathogen with a high risk for development of resistance (www.frac.info). Indeed, field isolates of $P$. cubensis with resistance to most sitespecific oomycete fungicides have been documented, including metalaxyl (Reuveni et al. 1980), strobilurins (Heaney et al. 2000; Ishii et al. 2001), fluopicolide (Thomas et al. 2018), cymoxanil, and propamocarb (Hübschová and Lebeda 2010; Pavelková et al. 2014). Resistance to carboxylic acid amines (CAAs) was documented in isolates from plastic-house-grown cucumber in China (Zhu et al. 2007) and in field isolates from the eastern United States (Blum et al. 2011). Moreover, field trials evaluating fungicide programs in the eastern United States suggested widespread prevalence of populations with multiple fungicide resistance (Adams et al. 2013; Colucci and Holmes 2007; Colucci et al. 2008; Hausbeck and Cortright 2009; Keinath et al. 2008).

Resistance to site-specific fungicides serves as an impetus for discovery and development of fungicides with a new mode of action. 
One such fungicide is oxathiapiprolin, which was recently discovered by DuPont Crop Protection (Pasteris et al. 2016; Sweigard et al. 2014). Oxathiapiprolin is the first member of a new class of piperidinyl thiazole isoxazoline fungicides that is currently being commercialized jointly by DuPont and Syngenta for control of diseases caused by oomycetes including cucurbit downy mildew. It acts by inhibiting a novel fungal target-an oxysterol binding protein (FRAC code 49) — and is intrinsically highly active against oomycetes causing leaf blights and downy mildews (Sweigard et al. 2014).

Recently, Cohen (2015) studied the activity of oxathiapiprolin against $P$. cubensis and showed that it inhibited all stages of growth at very low doses. However, to understand how best to deploy this fungicide for management of cucurbit downy mildew, there is a need to elucidate how pathogen inhibition relates to practical disease control and to compare the performance of oxathiapiprolinbased fungicide products with that of commercial standards. For example, cucumber plants undergo rapid vegetative growth and leaf expansion, with some cultivars flowering within a month after planting (Walters and Wehner 1994). Such a rapid growth results in newly emerged leaves and tissue formed during leaf expansion in the time interval between spray applications. Protecting this new growth presents a challenge to chemical-based control of downy mildew; fungicides need to either be systemic (capable of redistribution) or be applied frequently enough to protect the newly formed tissue. Moreover, to mitigate risk of resistance development, oxathiapiprolin is mostly commercialized as premix products, which were not evaluated by Cohen (2015). The goal of this study, therefore, was to characterize biological attributes of oxathiapiprolinbased fungicides that impact cucurbit downy mildew control relative to those of commercial standards. The specific objectives were to (i) evaluate the preventive, curative, and antisporulation activity of oxathiapiprolin-based fungicides, (ii) document the redistribution and systemic movement of the active ingredient in cucumber tissue using bioassays, and (iii) determine the effectiveness of oxathiapiprolin fungicides in protecting new tissue that develops between fungicide sprays.

\section{Materials and Methods}

Plant material and inoculum preparation. Cucumber plants, cultivar Straight 8 or Better Bush Improved, were grown in a walk-in controlled environment growth chamber (Controlled Environments, Pembina, ND) in 10-cm plastic pots filled with Rediearth potting medium (Sun Gro Horticulture, Anderson, SC). The plants were watered regularly and maintained for 14 days in a growth chamber at $20^{\circ} \mathrm{C}, 70 \%$ relative humidity $(\mathrm{RH})$, and 16 -h photoperiod prior to study initiation. Inoculum for the studies was prepared from a $P$. cubensis isolate obtained in 2014 from a research farm at the DuPont Stine-Haskell Research Center in Newark, DE (U.S.A.). The isolate was single-spored on detached leaves and maintained on 2-week-old cultivar Bush Champion cucumber stock plants in a growth chamber. For inoculum production, stock plants inoculated with the isolate and held in a growth chamber for 6 days were incubated for $24 \mathrm{~h}$ in a dew chamber at $20^{\circ} \mathrm{C}$ and $100 \% \mathrm{RH}$ in the dark to induce sporulation. Sporangia were harvested by washing the leaves in chilled $\left(4^{\circ} \mathrm{C}\right)$ Milli-Q water; the titer was determined with a hemocytometer and adjusted to the desired concentration. The sporangial suspension was applied using a pressurized handgun-type applicator.

Fungicide application. Depending on the study, oxathiapiprolinbased fungicides were compared with commercial formulations of cymoxanil + mancozeb (Curzate M; DuPont, Wilmington, DE), fluopicolide + propamocarb (Infinito; Bayer Crop Science, Cambridge, U.K.), mandipropamid (Revus; Syngenta Crop Protection, Greensboro, NC), mefenoxam + mancozeb (Ridomil Gold MZ; Syngenta Crop Protection), or ametoctradin + dimethomorph (Zampro; BASF Corporation, Research Triangle Park, NC). These fungicides were selected either because they are important for cucurbit downy mildew control in major producing countries or as standard for some of the biological attributes. Fluopicolide + propamocarb and mefenoxam + mancozeb are the commercial standards for cucurbit downy mildew control in China, the largest producer of cucurbits globally. Likewise, cymoxanil and mefenoxam were included as standards for assessing curative activity and systemic movement, respectively. Table 1 lists the fungicides and application doses of the products used in specific studies. Application doses used in these studies were based on recommended commercial use rates. In all studies, the fungicide products were suspended in water and applied using an automated sprayer with a single nozzle boom consisting of a TJ8002E nozzle calibrated to deliver a spray volume of 500 liters/ha at $206.8 \mathrm{kPa}$ pressure from a height of $30 \mathrm{~cm}$ above the plant canopy. These application settings ensured uniform coverage of the exposed leaf area without resulting in spray run-off. Following fungicide application, plants were left to dry for $1 \mathrm{~h}$ at ambient temperature $\left(\sim 20^{\circ} \mathrm{C}\right)$ before the subsequent experimental steps.

Evaluation of preventive and curative activity against $\boldsymbol{P}$. cubensis. The effectiveness of oxathiapiprolin in preventing infection (preinfection treatment) or inhibiting disease development on infected cucumber tissue (curative or postinfection treatment) was investigated in separate growth chamber studies and compared with that of commercial fungicides used for downy mildew control. In the preventive study, one experiment evaluated oxathiapiprolin formulated as a solo oil dispersion (OD) product, whereas another one evaluated the active ingredient in different premix products formulated as a suspoemulsion (SE) or water-dispersible granules (WG). All three oxathiapiprolin formulations were included in the curative study. Plants used for the preventive and curative studies were treated similarly except for the sequence of fungicide application relative to inoculation and the titer of the inoculum used. For the preventive study, fungicides were applied $24 \mathrm{~h}$ before the plants were inoculated with a suspension of 15,000 sporangia/ml of $P$. cubensis inoculum using a hand-held sprayer. For assessment of curative activity, plants were inoculated with a suspension of 5,000 sporangia/ml followed by fungicide application after 24 or $48 \mathrm{~h}$. Immediately following

Table 1. Fungicide products, constituent active ingredients, and application rates used in the studies

\begin{tabular}{|c|c|c|c|c|c|c|}
\hline Fungicide product & $\begin{array}{l}\text { Active ingredient(s) and } \\
\text { concentration(s) }(\mathbf{s})^{\mathbf{w}}\end{array}$ & $\begin{array}{l}\text { Application } \\
\text { rate (gai/ha) }\end{array}$ & $\begin{array}{l}\text { Preventive and } \\
\text { curative }^{\mathrm{y}}\end{array}$ & $\begin{array}{c}\text { Effect on } \\
\text { sporulation }\end{array}$ & $\begin{array}{l}\text { Local systemic } \\
\text { movement }\end{array}$ & $\begin{array}{l}\text { Protection of } \\
\text { new growth }\end{array}$ \\
\hline Zorvec Enicade & Oxathiapiprolin (100 g/liter) & 15 & $\bullet$ & $\bullet$ & - & - \\
\hline Zorvec Enibel ${ }^{\mathrm{z}}$ & Oxathiapiprolin + mancozeb $(0.6 \%+60 \% \mathrm{w} / \mathrm{w})$ & 1,515 & 0 & 0 & - & 0 \\
\hline Zorvec Encantia ${ }^{\mathrm{z}}$ & Oxathiapiprolin + famoxadone $(30+300 \mathrm{~g} / \mathrm{liter})$ & 165 & 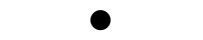 & 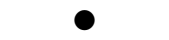 & $\bullet$ & 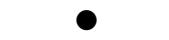 \\
\hline Revus & Mandipropamid (250 g/liter) & 150 & ○ & ○ & $\ldots$ & ○ \\
\hline Ridomil Gold MZ & Mefenoxam + mancozeb $(4 \%+64 \%$ w/w $)$ & 1,700 & $\bullet$ & $\bullet$ & $\bullet$ & $\bullet$ \\
\hline Infinito & Fluopicolide + propamocarb $(62.5+625 \mathrm{~g} /$ liter $)$ & 1,100 & $\bullet$ & $\bullet$ & $\bullet$ & $\bullet$ \\
\hline Curzate M & Cymoxanil + mancozeb $(4.5 \%+68 \% \mathrm{w} / \mathrm{w})$ & 1,650 & ○ & $\ldots$ & 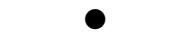 & 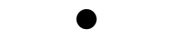 \\
\hline Zampro & Ametoctradin + dimethomorph $(300+225 \mathrm{~g} /$ liter $)$ & 540 & $\bullet$ & $\ldots$ & $\bullet$ & $\ldots$ \\
\hline Nontreated control & $\ldots$ & $\ldots$ & ○ & ○ & • & 0 \\
\hline
\end{tabular}

\footnotetext{
${ }^{w}$ Values in parentheses indicate the amount of active ingredient per unit of formulated product.

${ }^{x}$ gai/ha $=$ grams active ingredient per hectare; doses of oxathiapiprolin-based fungicides were calculated to deliver 15 gai/ha.

y A filled circle indicates testing was conducted; an ellipsis indicates no data.

${ }^{z}$ DuPont oxathiapiprolin-based experimental fungicide premix products.
} 
inoculation, the plants were placed in a dark dew chamber set at $20^{\circ} \mathrm{C}$ and $100 \%$ RH for $24 \mathrm{~h}$. Plants were then moved to a growth chamber at $20^{\circ} \mathrm{C}, 70 \% \mathrm{RH}$, and a $16-\mathrm{h}$ photoperiod for the remainder of the study. Plants were evaluated for disease development 5 or 6 days after inoculation for the preventive and curative activity experiments, respectively. Disease severity was visually estimated as percent leaf area with symptoms of downy mildew on the oldest leaf of each plant

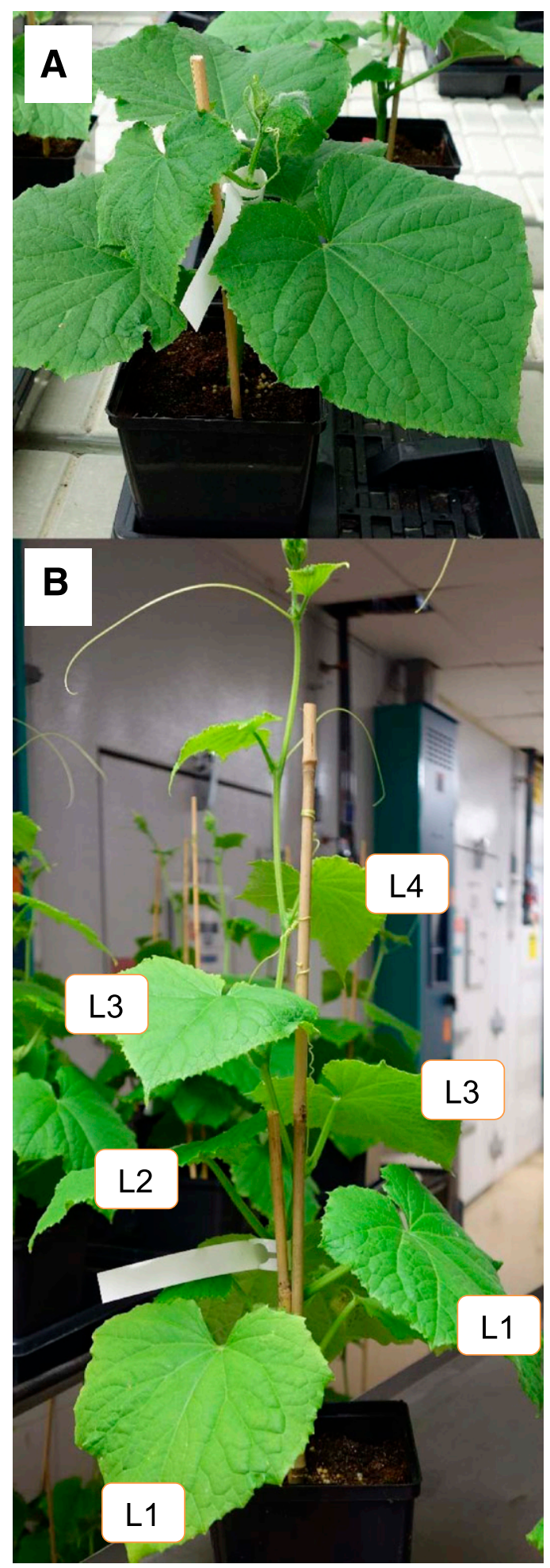

Fig. 1. Growth stage and size of cucumber plants at the time of $\mathrm{A}$, fungicide treatment application and $B$, inoculation 9 days later. Numbered leaves ( $L 1$ to $L 4)$ in $B$ represent growth stages at the time of fungicide application: $\mathrm{L} 1=$ fully expanded leaf, $\mathrm{L} 2=$ expanding leaf, $L 3=$ emerging leaf, and $L 4=$ completely new growth that was not present in $\mathrm{A}$. (which was fully expanded at the time of fungicide application) with the aid of standard area diagrams (Michereff et al. 2009). The experimental design in all trials was a randomized complete block with each treatment replicated on six plants. Each experiment was conducted three times.

Effects on lesion expansion and spore production. Cucumber plants were inoculated $48 \mathrm{~h}$ prior to fungicide application with a 5 - $\mu l$ droplet $(10,000$ sporangia/ml $)$ that was placed next to the midvein of the first true leaf of each plant. Plants were then incubated in a dew chamber at $20^{\circ} \mathrm{C}$ and $100 \% \mathrm{RH}$ without light for $24 \mathrm{~h}$. Plants were then moved to a growth chamber set at $23^{\circ} \mathrm{C}$ and $70 \% \mathrm{RH}$ during the $16-\mathrm{h}$ photoperiod and at $20^{\circ} \mathrm{C}$ and $70 \% \mathrm{RH}$ during the 8 -h dark period each day until fungicide application. Fungicides were applied following procedures described above. The plants were evaluated for lesion size and sporangial production 6 days after inoculation. Before evaluation, the plants were placed in a dew chamber set at $20^{\circ} \mathrm{C}$ and $100 \% \mathrm{RH}$ for $24 \mathrm{~h}$ to induce sporulation. Inoculated leaves were then excised, and the lesion size on each leaf was determined by tracing the outline of the lesion onto a transparent tracing paper. The area within the traced outline was colored in black, and the lesion size $\left(\mathrm{cm}^{2}\right)$ was measured using an LI-3100 area meter (LI-Cor Biosciences, Lincoln, NE). Individual lesions were then cut out and placed into 50-ml centrifuge tubes containing $10 \mathrm{ml}$ of deionized water. Sporangia were dislodged from the lesions by vortexing the tubes for $15 \mathrm{~s}$ and counted using a hemocytometer. The fungicide treatments evaluated (Table 1) were assigned in a randomized complete-block design replicated on six plants each with a single lesion. The experiment was conducted three times.

Evaluation of local systemic movement. Local systemic movement of oxathiapiprolin in cucumber tissue was investigated using a bioassay designed to quantify the protection of leaf tissue not directly in contact with fungicide spray droplets. Before fungicide application, a piece of aluminum foil was wrapped tightly around the outer half portion of the first true leaf of each plant (hereafter referred to as the protected portion) to protect it from fungicide spray. One fully expanded leaf per plant was covered. Fungicides were applied using the same equipment and settings described above following a procedure that ensured coverage of the exposed leaf area with fine droplets without resulting in spray run-off. Following fungicide application, the plants were left to dry for $1 \mathrm{~h}$ at room temperature $\left(\sim 20^{\circ} \mathrm{C}\right)$ before the protective foil was removed from the leaves. Plants were inoculated $24 \mathrm{~h}$ after fungicide application, incubated in a dew chamber overnight, and maintained in a growth chamber with the same settings as described for the preventive study. Plants were evaluated visually for disease severity as described above. Only the leaf that had been partially covered with the aluminum foil was evaluated. Two separate portions of the leaf were evaluated: (i) the exposed (i.e., treated) portion of the leaf closest to the main stem of the plant and (ii) the protected (i.e., untreated) half portion of the leaf toward the tip.

Two separate experiments distinguished by the formulation of oxathiapiprolin-based fungicides described above for the preventive study were carried out (Table 1). Each experiment was set up as a randomized complete block design with six replicate plants per experiment, and three runs of each experiment were completed.

Protection of new growth. The ability of oxathiapiprolin to protect cucumber tissue during periods of rapid plant growth and leaf expansion was compared with that of commercial standard fungicides in two greenhouse experiments (hereafter referred to as experiment 1 and experiment 2). The distinction between the two experiments was oxathiapiprolin formulation used as described for the preventive study. Plants established in $10-\mathrm{cm}$ pots as described previously were transplanted into 14-cm pots filled with Redi-earth and grown in a greenhouse set at $25 \pm 2{ }^{\circ} \mathrm{C}$ for an additional week until they had developed three fully expanded leaves. Prior to fungicide application, each plant was secured with a bamboo peg and tagged just above the third fully expanded leaf (Fig. 1A). After fungicide application, the plants were left to dry for $1 \mathrm{~h}$ and moved back to the greenhouse for continued growth for a period of 8 days. The plants were then inoculated as described for the preventive test. Following inoculation, 
the plants were immediately incubated in a dew chamber for $24 \mathrm{~h}$, after which they were moved back to the greenhouse until evaluation.

Plants were evaluated for disease severity 5 days after inoculation, as described previously. The leaves were assigned to categories based on their growth stage and expansion at the time of fungicide application, and data on disease severity were recorded separately for each category. The four categories were: (i) fully expanded leaves (L1), meaning the three oldest leaves that were in full size at the time of fungicide application and located below the tag; (ii) expanding leaf (L2), meaning the leaf located just above the fullsized leaves that was 30 to $50 \%$ of final size at time of fungicide application; (iii) emerging leaves (L3), meaning leaves that were $<30 \%$ of final size by the time of fungicide application; and (iv) new growth (L4), meaning the youngest leaf not visible at the time of treatment application (i.e., not exposed to fungicides).

The fungicide treatments evaluated, the method and equipment used for fungicide application were identical to those described above for the local systemic movement study. For both experiments, each treatment (Table 1) was randomly allocated to single plant per replicate. Experiment 1 was repeated once with eight and seven single plant replicates used for the first and second runs, respectively. Experiment 2 was repeated two times using eight replicates per treatment in each run. Disease severity data were obtained as described for preventive study and analyzed separately for experiments 1 and 2 .

Statistical analysis. Evaluation of preventive and curative activity. Combined data from the three runs of each experiment were analyzed using the MIXED procedure of SAS 9.4 (SAS Institute, Cary, NC).

Evaluation of local systemic movement. Preliminary analyses determined there were no differences among repeats of the individual experiments $(P=0.385$ and 0.219 for data on the protected and exposed portions, respectively), so the data were combined for analysis.
Protection of new growth. Data from each experiment were analyzed as a split-plot design using a mixed model approach. The fungicide treatments and leaf levels were specified as whole-plot and subplot fixed effects factors, respectively, whereas the experimental runs were specified as a random effects term in the model.

Data from experiments on lesion expansion, spore production, systemic movement, and protection of new growth were analyzed using the GLIMMIX procedure of SAS 9.4.

For all experiments, treatment mean separations were computed using the lsmeans statement with a Tukey-Kramer adjustment.

\section{Results}

Preventive and curative activity against $P$. cubensis. In the preventive study, severe downy mildew symptoms developed on the nontreated plants with disease severity averaging $79.6 \%$ for the experiment evaluating the oxathiapiprolin solo OD formulation and $98.0 \%$ in the experiment assessing the different premix products (Table 2). All fungicides evaluated for preventive control significantly reduced disease relative to the nontreated control $(P<$ 0.0001 ; Table 2), with oxathiapiprolin-based products being among the most effective. On plants treated with the oxathiapiprolin OD formulation, downy mildew severity averaged $0.4 \%$ in the three experiments but was not significantly different from plants treated with either mefenoxam + mancozeb $(1.6 \%)$ or propamocarb + fluopicolide premix products $(2.7 \%)$. No disease developed on plants preventively treated with the oxathiapiprolin SE and WG premix fungicides. Mandipropamid was the least effective fungicide at preventing infection, with disease severity averaging 41.3 and $86.7 \%$ in the two experiments (Table 2).

When applied postinfection, all oxathiapiprolin-based fungicides significantly inhibited disease development $(P<0.0001$; Table 3$)$.

Table 2. Effects of preventive application of oxathiapiprolin products on the development of cucurbit downy mildew (Pseudoperonospora cubensis) in growth chamber studies

\begin{tabular}{|c|c|c|c|c|}
\hline \multirow[b]{2}{*}{ Fungicide treatment } & \multirow[b]{2}{*}{ Formulation $^{x}$} & \multirow[b]{2}{*}{ Application rate (gai/ha)y } & \multicolumn{2}{|c|}{ Mean downy mildew severity $(\%)^{z}$} \\
\hline & & & Experiment 1 & Experiment 2 \\
\hline Untreated check & $\ldots$ & $\ldots$ & $79.6 \mathrm{a}$ & $98.0 \mathrm{a}$ \\
\hline Mandipropamid & $\mathrm{SC}$ & 150 & $41.3 \mathrm{~b}$ & $86.7 \mathrm{~b}$ \\
\hline Oxathiapiprolin & OD & 15 & $0.4 \mathrm{c}$ & $\ldots$ \\
\hline Mefenoxam + mancozeb & WP & 1,700 & $1.6 \mathrm{c}$ & $5.6 \mathrm{c}$ \\
\hline Oxathiapiprolin + mancozeb & WG & 1,515 & $\ldots$ & $0.0 \mathrm{~d}$ \\
\hline Fluopicolide + propamocarb & SC & 1,100 & $2.7 \mathrm{c}$ & $0.0 \mathrm{~d}$ \\
\hline Oxathiapiprolin + famoxadone & SE & 165 & $\ldots$ & $0.0 \mathrm{~d}$ \\
\hline Cymoxanil + mancozeb & WG & 1,650 & $\ldots$ & $0.4 \mathrm{~d}$ \\
\hline
\end{tabular}

Table 3. Effects of oxathiapiprolin formulations on postinfection activity against cucurbit downy mildew (Pseudoperonospora cubensis) in growth chamber studies

\begin{tabular}{|c|c|c|c|c|}
\hline \multirow[b]{2}{*}{ Fungicide treatment } & \multirow[b]{2}{*}{ Formulation $^{x}$} & \multirow[b]{2}{*}{ Application rate $(\mathrm{gai} / \mathrm{ha})^{\mathrm{y}}$} & \multicolumn{2}{|c|}{ Mean downy mildew severity $(\%)^{z}$} \\
\hline & & & 1-day curative test & 2-day curative test \\
\hline Untreated check & $\ldots$ & $\ldots$ & $85.2 \mathrm{a}$ & $89.3 \mathrm{a}$ \\
\hline Mandipropamid & SC & 150 & $79.6 \mathrm{ab}$ & $84.2 \mathrm{a}$ \\
\hline Oxathiapiprolin & OD & 15 & $6.1 \mathrm{de}$ & $41.9 \mathrm{e}$ \\
\hline Ametoctradin + dimethomorph & $\mathrm{SC}$ & 540 & $81.7 \mathrm{a}$ & $84.2 \mathrm{a}$ \\
\hline Mefenoxam + mancozeb & WP & 1,700 & $72.7 \mathrm{~b}$ & $68.1 \mathrm{~b}$ \\
\hline Oxathiapiprolin + mancozeb & WG & 1,515 & $17.7 \mathrm{c}$ & $50.8 \mathrm{~cd}$ \\
\hline Fluopicolide + propamocarb & SC & 1,100 & $13.2 \mathrm{~cd}$ & $52.5 \mathrm{c}$ \\
\hline Oxathiapiprolin + famoxadone & SE & 165 & 10.2 cde & 46.1 cde \\
\hline Cymoxanil + mancozeb & WG & 1,650 & $3.8 \mathrm{e}$ & 45.8 cde \\
\hline
\end{tabular}

Formulation type: $\mathrm{OD}=$ oil dispersion; $\mathrm{SC}=$ suspension concentrate; $\mathrm{SE}=$ suspoemulsion; WG = water-dispersible granule; and WP = wettable powder.

${ }^{\mathrm{y}}$ gai/ha = grams active ingredient per hectare; doses for all oxathiapiprolin products deliver 15 gai/ha.

${ }^{\mathrm{z}}$ Values are means of three experimental runs with each treatment replicated on six plants. Means followed by the same letter within a column are not significantly different based on Tukey's HSD test $(\alpha=0.05)$ 
Among the standards, the cymoxanil-containing product had the highest level of 1-day curative activity, which was equivalent to the OD formulation of oxathiapiprolin. Fluopicolide + propamocarb also provided a high level of disease control postinfection that was comparable to the SE and WG formulations of oxathiapiprolin-based products in the 1-day curative assay. By contrast, mandipropamid and ametoctradin + dimethomorph did not reduce disease relative to the nontreated control (Table 3). There was a significant formulation effect on the postinfection activity of the oxathiapiprolin-based products whereby the oxathiapiprolin OD formulation was significantly more inhibitory than the oxathiapiprolin + mancozeb WG formulation $(0.001 \leq P \leq$ 0.049 ; Table 3) but not statistically different from the oxathiapiprolin + famoxadone SE formulation.

Effects on lesion expansion and spore production. All oxathiapiprolin-based fungicides significantly inhibited lesion development, resulting in a mean lesion size $<0.33 \mathrm{~cm}^{2}$, which was significantly smaller than $0.51 \mathrm{~cm}^{2}$ observed for fluopicolide + propamocarb $(0.001 \leq P \leq 0.038$; Fig. $2 \mathrm{~A})$. By contrast, lesion sizes for plants treated with mefenoxam + mancozeb, mandipropamid, or ametoctradin + dimethomorph were $>1 \mathrm{~cm}^{2}$ but were significantly $(P<0.001)$ smaller than those on the nontreated plants. No sporangia developed on plants treated with the oxathiapiprolin OD or oxathiapiprolin-based SE fungicides (Fig. 2B). The highest number of sporangia were obtained from plants treated with ametoctradin + dimethomorph, mandipropamid, and mefenoxam + mancozeb. Relatively low numbers of sporangia were obtained from lesions of plants treated with the oxathiapiprolin-based WG fungicide and

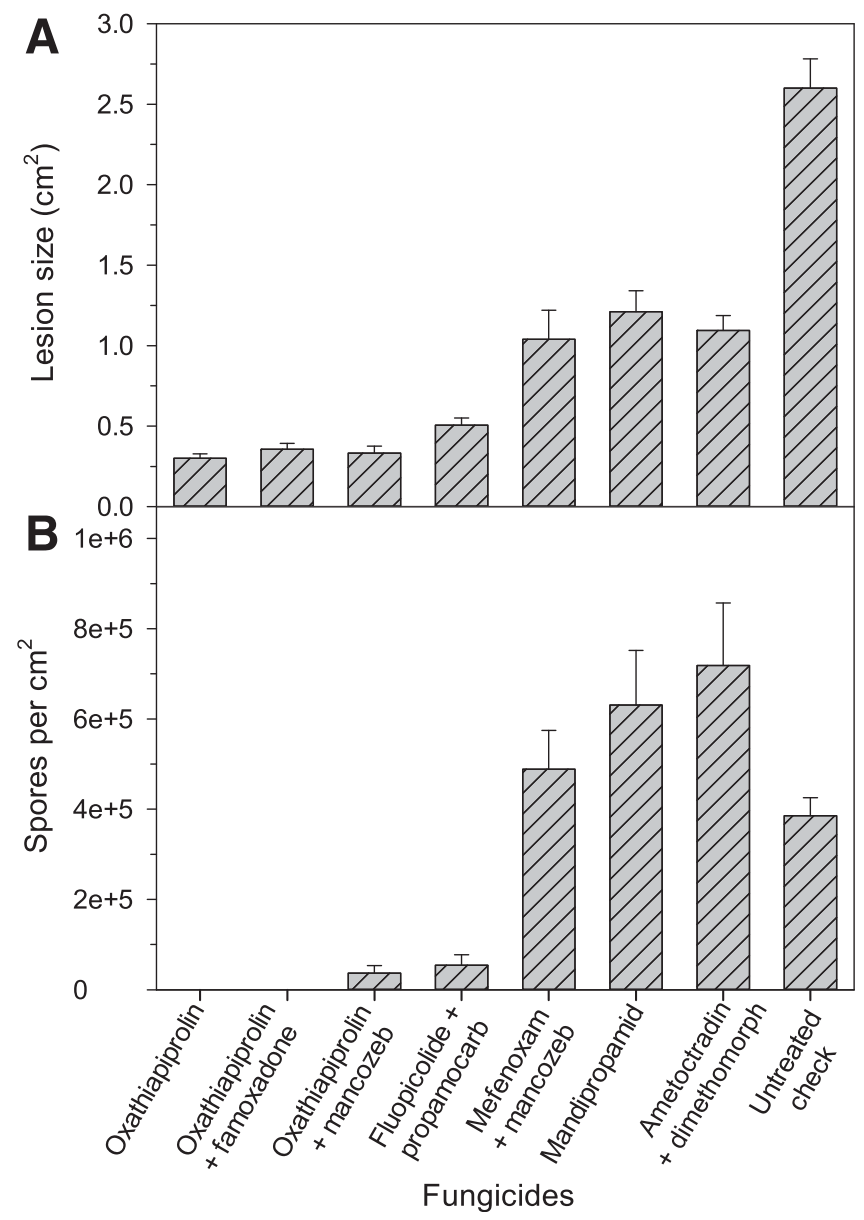

Fig. 2. Effects of oxathiapiprolin-based fungicides and commercial fungicide standards on $\mathbf{A}$, cucumber downy mildew lesion size and $\mathbf{B}$, number of spores per lesion on cucumber leaves inoculated $24 \mathrm{~h}$ after fungicide application. All oxathiapiprolinbased fungicides were applied at a rate that delivered $15 \mathrm{~g}$ of active ingredient per hectare, whereas commercial fungicide standards were tested at their label rates (Table 1). Values are means and standard deviations of 12 replicate plants. fluopicolide + propamocarb, but these were an order of magnitude lower than those observed for the other fungicides in the experiment (Fig. 2B).

Evaluation of local systemic movement. Relative to the nontreated plants, all fungicides inhibited disease development on the exposed leaf portions (i.e., tissue in contact with the fungicides), with hardly any infection occurring on leaves treated with oxathiapiprolin products (maximum disease severity $=0.7 \%$ in both experiments). Disease severity on protected leaf portions averaged $6.6 \%$ for plants treated with the OD formulation of oxathiapiprolin in the first experiment compared with $1.6 \%$ in the second experiment (Table 4). In comparison, disease severity on such portions averaged 2.7 and $3.8 \%$ for SE and WG oxathiapiprolin-based fungicides in the second experiment, respectively (Table 4). These levels of disease were significantly lower than 84.9 and $83.3 \%$ observed for the nontreated controls in the two experiments, respectively $(P<0.001$; Table 4$)$. By contrast, disease severity on the protected leaf sections was 23.7 and $10.9 \%$ for plants treated with fluopicolide + propamocarb and 40.3 and $51.4 \%$ for those treated with mefenoxam + mancozeb in the two experiments, respectively (Table 4). Among the oxathiapiprolin-based fungicides tested in the second experiment, the highest level of disease on the protected portions was observed on plants treated with the WG formulation $(3.8 \%)$, for which disease control was not significantly greater than that observed for similar portions of plants treated with fluopicolide + propamocarb $(10.9 \%$; Table 4). High levels of disease were observed on protected leaf portions of plants treated with ametoctradin + dimethomorph $(60 \%)$.

Protection of new growth. Between fungicide application and inoculation, the plants grew up to four new leaves at various stages of development (Fig. 1B). In both experiments, type III analysis of fixed effects indicated a significant $(P<0.0001)$ result for experimental runs and for interactions between fungicide and leaf growth stage. Data were therefore summarized separately for each experimental run (Figs. 3 and 4). In experiment 1, severe downy mildew developed on leaves that were fully expanded or expanding on the nontreated plants, with disease severity averaging 87.6 and $85.7 \%$ in the first experimental run and 82.5 and $78.8 \%$ in the second run, respectively (Fig. 3). On the same nontreated plants, significantly less downy mildew developed on leaves that had not emerged at the time of fungicide application $(P<0.0001 ;$ Fig. 3$)$. Overall, the oxathiapiprolin OD formulation was the most effective fungicide, providing almost complete protection to the fully expanded, expanding, and emerging leaves. In addition, this treatment significantly reduced disease severity on leaves that had not emerged at the time of fungicide application (new growth) by 60.5 and $75.7 \%$ relative to similar leaves of the nontreated plants $(P<0.0001 ;$ Fig. 3$)$. Downy mildew severity on emerging leaves and new growth was significantly lower in plants treated with oxathiapiprolin than those protected with either the fluopicolide + propamocarb or mefenoxam + mancozeb premix products. Furthermore, fluopicolide + propamocarb did not significantly reduce disease on the new growth relative to the nontreated control $(P=0.816$ and 1.0; Fig. 3), while the results for mefenoxam + mancozeb were not consistent among the experimental runs $(P=0.737$ and 0.015 ; Fig. 3).

The patterns of downy mildew development and fungicide effects were similar for the first two runs of experiment 2 . Regardless of the stage of leaf growth at the time of fungicide application, disease severity on the nontreated plants averaged $>78 \%$ in the first two runs of the experiment (Figs. 4 and 5). However, in the third experimental run disease severity on the nontreated plants was $>75 \%$ on the fully expanded, expanding, and emerging leaves but was significantly lower for the new growth not present at the time of fungicide application $(49.5 \% ; P<0.0001$; Fig. 4C). Across the three experimental runs, all fungicide treatments significantly $(P<0.0001)$ reduced downy mildew severity relative to the nontreated control on all leaf growth stages except for the new growth (Figs. 4 and 5). With the exception of a single comparison (Fig. 4A), disease severity on the leaves that were fully expanded, expanding, or emerging at the time of fungicide application was significantly lower on plants treated with oxathiapiprolin-based fungicides than those treated with either 
the fluopicolide + propamocarb and mefenoxam + mancozeb premix products. Only the oxathiapiprolin-based fungicides consistently protected new growth across the three experimental runs $(0.036 \leq$ $P \leq 0.0001$; Fig. 4). The mefenoxam + mancozeb premix product significantly reduced disease severity on new growth in only one of three experimental runs $(P=0.032$; Figs. $4 \mathrm{~A}$ and $5 \mathrm{~F})$. Fluopicolide + propamocarb did not significantly reduce downy mildew severity on leaves that had not emerged at the time of application in any of the tests ( $P>0.05$; Figs. 4 and 5D).

\section{Discussion}

The successful deployment of any fungicide product requires a good understanding of its performance and activity on plants under different environmental conditions. In this study, we investigated the pre- and postinfection performance, local systemic activity, and protection of new, untreated growth from treatments with the newly registered oomycete fungicide oxathiapiprolin (Pasteris et al. 2016; Sweigard et al. 2014), for the control of cucurbit downy mildew under controlled environmental conditions. Oxathiapiprolin provided both preventive and postinfection control of our in-house $P$. cubensis isolate that was similar to or greater than that of the commercial products included for comparison. It must be noted that no attempt was made to confirm the sensitivity profile of our isolate to other fungicides; therefore, we cannot exclude the possibility of partial insensitivity to CAA or phenylamide (PA) fungicides.

Consistent with observations of Cohen (2015), the effects of oxathiapiprolin-based formulations on downy mildew development also depended on the timing of application relative to host infection. When applied preventively at the commercial dose rate, oxathiapiprolin-based fungicides completely inhibited infection; when applied curatively within $24 \mathrm{~h}$ postinoculation, these fungicides significantly inhibited disease development, reducing severity by $>90 \%$. However, the level of inhibition declined to $<60 \%$ when applications were delayed to $48 \mathrm{~h}$ postinfection. This decline in the level of disease control was, however, not surprising, because $P$. cubensis rapidly colonizes host tissue prior to disease symptoms becoming apparent 4 days postinfection (Savory et al. 2011; Thomas 1996).

Disease control from 1 day postinfection applications of mandipropamid (5.7 to $6.6 \%$ ) and mefenoxam + mancozeb (14.6 to $23.7 \%$ ) was surprisingly low in these experiments (Table 3), considering that both molecules are reported to have curative activity on P. cubensis (Lebeda and Cohen 2011). Partial resistance of our inhouse isolate to these active ingredients is a possible explanation for their relatively poor performance in this study.

The studies on lesion expansion and sporulation indicated that oxathiapiprolin inhibits both mycelial growth and sporangia production. Based on these observations, oxathiapiprolin-based fungicides, if applied postinfection, can be expected to slow down cucurbit downy mildew epidemics by reducing the amount of inoculum available to initiate secondary infections. Although this is an important biological property of oxathiapiprolin, preventative applications are recommended on most oxathiapiprolin product labels to mitigate the risk of resistance development. Given that $P$. cubensis mycelia

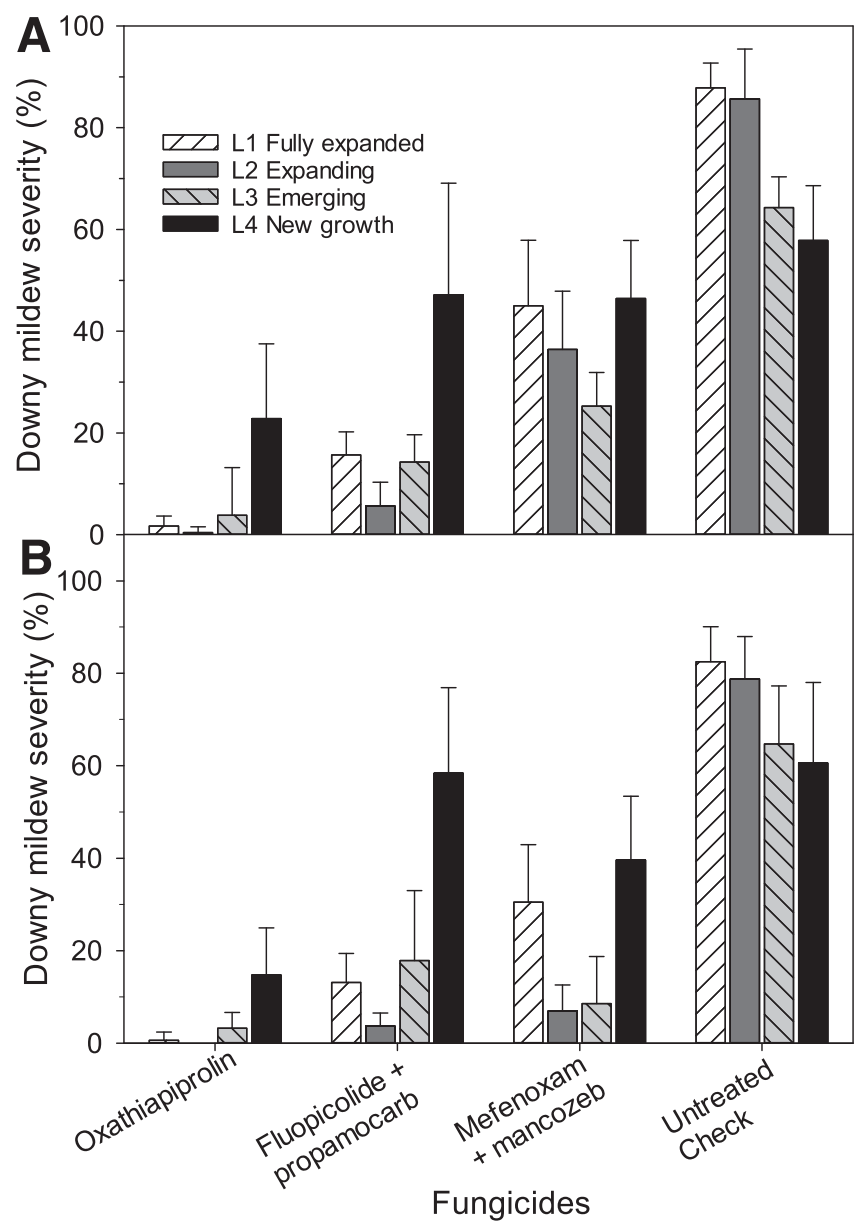

Fig. 3. Effects of oxathiapiprolin solo formulation and commercial fungicide standards on protection of new growth of cucumber from downy mildew in separate experiments (A and B) of a greenhouse experiment. Based on their stage of development at the time of fungicide application, the leaves were classified as fully expanded, expanding, emerging, and new growth (i.e., not visible at the time of treatment application and therefore not directly exposed to fungicides). Values are means and standard deviations of eight and seven replicate plants in A and B, respectively.

Table 4. Effects of local systemic movement of oxathiapiprolin products on the development of cucurbit downy mildew (Pseudoperonospora cubensis) in growth chamber studies

\begin{tabular}{|c|c|c|c|c|c|c|}
\hline \multirow[b]{2}{*}{ Fungicide treatment } & \multirow[b]{2}{*}{ Formulation $^{w}$} & \multirow[b]{2}{*}{$\begin{array}{l}\text { Application } \\
\text { rate }(\text { gai/ha })^{\mathrm{x}}\end{array}$} & \multicolumn{2}{|c|}{$\begin{array}{c}\text { Mean downy mildew severity } \\
\text { experiment } 1\end{array}$} & \multicolumn{2}{|c|}{$\begin{array}{c}\text { Mean downy mildew severity } \\
\text { experiment } 2\end{array}$} \\
\hline & & & $\begin{array}{l}\text { Protected leaf } \\
\text { section }^{\mathrm{z}}\end{array}$ & $\begin{array}{l}\text { Exposed leaf } \\
\text { section }\end{array}$ & $\begin{array}{l}\text { Protected leaf } \\
\text { section }^{\mathrm{z}}\end{array}$ & $\begin{array}{l}\text { Exposed leaf } \\
\text { section }\end{array}$ \\
\hline Untreated check & $\ldots$ & $\ldots$ & $84.9 \mathrm{a}$ & $84.9 \mathrm{a}$ & $83.3 \mathrm{a}$ & $83.3 \mathrm{a}$ \\
\hline Oxathiapiprolin & OD & 15 & $6.6 \mathrm{~d}$ & $0.7 \mathrm{~b}$ & $1.6 \mathrm{e}$ & $0.0 \mathrm{c}$ \\
\hline Ametoctradin + dimethomorph & SC & 540 & $\ldots$ & $\ldots$ & $59.7 \mathrm{~b}$ & $4.9 \mathrm{~b}$ \\
\hline Mefenoxam + mancozeb & WP & 1,700 & $40.3 \mathrm{~b}$ & $1.2 \mathrm{~b}$ & $51.4 \mathrm{c}$ & $1.6 \mathrm{c}$ \\
\hline Fluopicolide + propamocarb & SC & 1,100 & $23.7 \mathrm{c}$ & $2.5 \mathrm{~b}$ & $10.9 \mathrm{~d}$ & $0.00 \mathrm{c}$ \\
\hline Oxathiapiprolin + mancozeb & WG & 1,515 & $\ldots$ & $\ldots$ & $3.8 \mathrm{de}$ & $0.00 \mathrm{c}$ \\
\hline Oxathiapiprolin + famoxadone & SE & 165 & $\ldots$ & $\ldots$ & $2.7 \mathrm{e}$ & $0.00 \mathrm{c}$ \\
\hline
\end{tabular}

${ }^{\mathrm{w}}$ Formulation type: $\mathrm{OD}=$ oil dispersion; $\mathrm{SC}=$ suspension concentrate; $\mathrm{SE}=$ suspoemulsion; $\mathrm{WG}=$ water-dispersible granule; and $\mathrm{WP}=$ wettable powder.

${ }^{\mathrm{x}}$ gai/ha = grams active ingredient per hectare; doses for all oxathiapiprolin products deliver 15 gai/ha.

y Values are means of two experimental runs each with six replicates per treatment. Means followed by the same letter within a column are not significantly different based on Tukey's HSD test $(\alpha=0.05)$.

${ }^{\mathrm{z}}$ Leaf sections wrapped with aluminum foil to protect them from fungicide spray. 
colonize and produce haustoria within mesophyll cells (Savory et al. 2011; Thomas 1996), in planta inhibition of lesion expansion along with the results of the postinfection studies indicated that oxathiapiprolin can penetrate the leaf cuticle and epidermal tissues and provided evidence for the initial steps in translaminar and systemic movement (Jacob and Neumann 1987; Klittich 2014; Zelená and Veverka 2007).

Our data on local systemic movement using a protected leaf bioassay indicated that oxathiapiprolin-based fungicides applied preventively at the label dose can protect tissue that was not in direct contact with the fungicide. In the absence of a vapor-phase activity for oxathiapiprolin, protection of tissue not in direct contact with

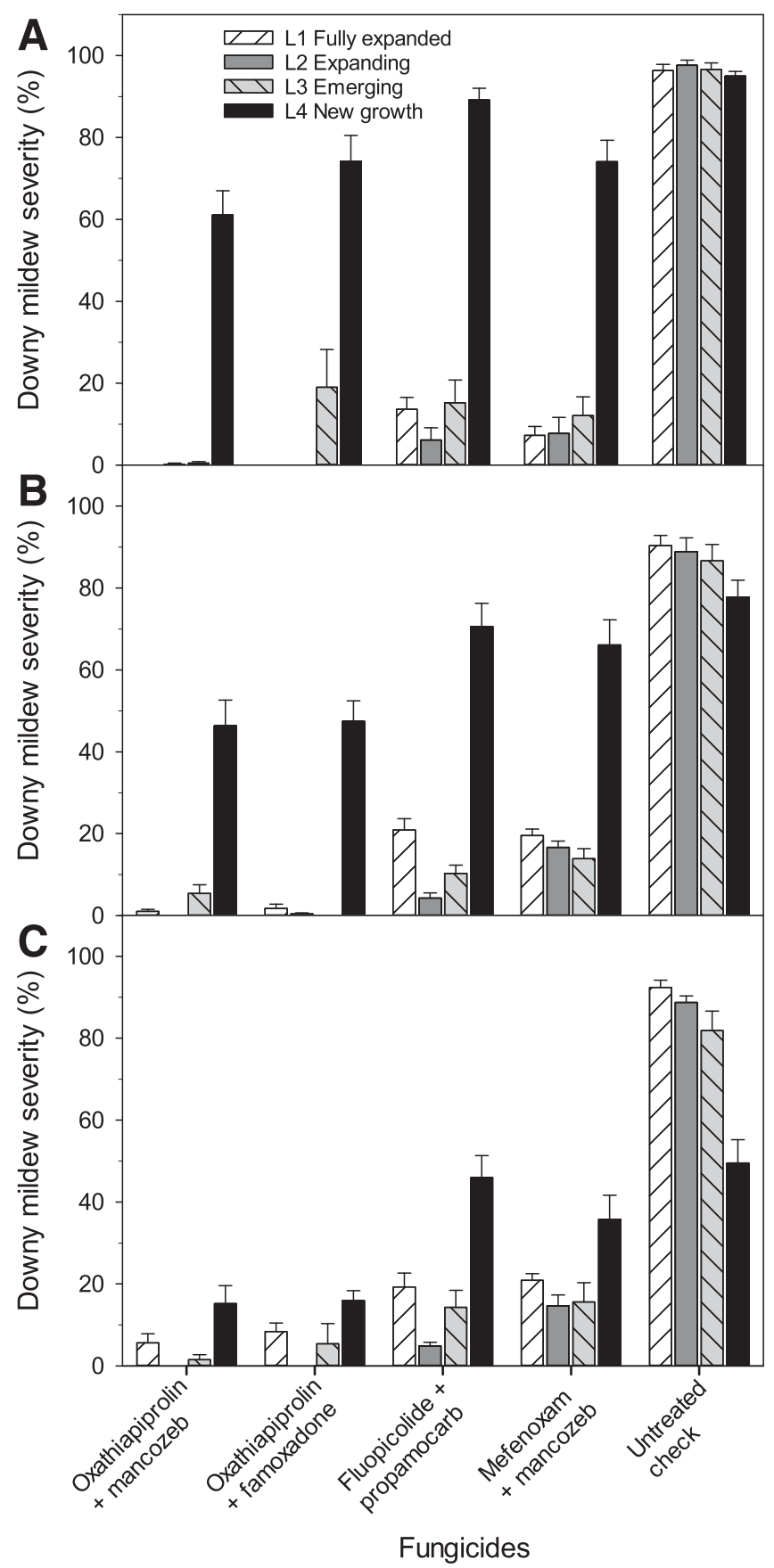

Fig. 4. Effects of oxathiapiprolin-based fungicides and commercial fungicide standards on protection of new growth of cucumber from downy mildew in three separate experiments (A, B, and C) of a greenhouse experiment. Based on their stage of development at the time of fungicide application, the leaves were classified as fully expanded, expanding, emerging, and new growth (i.e., not visible at the time of treatment application and therefore not directly exposed to fungicides). Values are means and standard deviations of eight replicate plants. spray droplets was indicative of systemic movement. These results therefore confirmed that oxathiapiprolin is locally systemic and concurred with those of Cohen (2015), who documented local systemic movement including translaminar movement in cucumber using a different experimental approach. Local systemic movement should allow oxathiapiprolin-based fungicides to compensate for variability in spray coverage typical of field and greenhouse application of fungicides, thereby enabling more uniform disease control in broadleafed crops with a dense canopy such as cucurbits (Ando and Grumet 2006).

In studies on protection of new growth, oxathiapiprolin-based fungicides consistently protected tissue that was not present at the time of application, reducing disease severity by at least $75 \%$ relative to nontreated plants when applied preventively to rapidly growing plants in a greenhouse. This observation is remarkable given that inoculations were carried out 8 to 9 days after fungicide application. The other fungicides evaluated in these studies protected expanding and emerging tissue that was already present at the time of application. However, the level of protection was consistently lower than that of oxathiapiprolin-based fungicides, and none of these fungicides protected leaves that had not emerged at the time of spray application. As stated earlier, the possibility for partial resistance of our in-house $P$. cubensis isolate to CAA or PA fungicides may have interfered with this outcome. Nevertheless, the practical implications of these results on protection of new growth is that oxathiapiprolinbased fungicides will contribute to the protection of cucumber leaf tissue formed during spray intervals. Although the duration of protection offered was not investigated beyond 9 days, this interval is sufficient to allow for flexibility in the timing of fungicide applications in commercial cucurbit production given that aggressive spray programs call for a 5- to 7-day spray interval (Gevens and Hausbeck 2006; Hausbeck and Cortright 2009; Savory et al. 2011). Moreover, this attribute will allow oxathiapiprolin-based fungicides to fit seamlessly into integrated cucurbit spray programs utilizing disease forecasting models (Holmes et al. 2004).

In general, less severe downy mildew developed on the new growth of nontreated control plants than on the fully expanded, expanding, and emerging leaves. This was probably owing to differences in leaf tissue susceptibility to downy mildew or dilution effects on the inoculum resulting from leaf expansion. Following inoculation and an initial 24-h incubation in a $100 \%$ RH dew chamber, the plants were maintained in a greenhouse set at $70 \% \mathrm{RH}$ and watered by pan flooding. These greenhouse conditions resulted in no free water on the leaf surfaces, which is a critical requirement for infection by $P$. cubensis (Palti and Cohen 1980; Savory et al. 2011; Thomas 1996). Nevertheless, disease severity on new growth of the nontreated plants was at least $50 \%$ in all experimental runs, which is sufficient to support the key conclusions on the magnitude of protection offered by oxathiapiprolin-based fungicides.

Several hypotheses can be advanced to account for the redistribution of oxathiapiprolin in cucumber tissue. Redistribution of an active ingredient can occur through vapor-phase diffusion, systemic and local systemic movement, or movement on the leaf surface (Klittich 2014). Several studies in our lab have established that oxathiapiprolin does not exhibit vapor-phase movement (Shepherd, unpublished), whereas our data clearly support systemic movement in agreement with Cohen (2015). Nonetheless, the redistribution effects of oxathiapiprolin observed in this study likely reflect a continuum of translaminar, local systemic, and perhaps some surface movement as new plant tissue develops.

It is interesting that oxathiapiprolin was relatively more effective at protecting new growth than fluopicolide + propamocarb or mefenoxam + mancozeb products, given that both mefenoxam and propamocarb are systemic (Kennelly et al. 2007; Kerkenaar and Sijpesteijn 1981). This observation may be owing to the significantly higher intrinsic activity of oxathiapiprolin relative to these fungicides or possibly, in the case of mefenoxam, to the partially reduced sensitivity of our $P$. cubensis isolate to PA fungicides. Oxathiapiprolin is intrinsically highly toxic to oomycete fungi, inhibiting $P$. cubensis spore germination at as low as $0.0001 \mathrm{mg} / \mathrm{liter}$ (Cohen 2015). High 
intrinsic activity of oxathiapiprolin has also been documented for other oomycetes including Phytophthora capsici (Ji and Csinos 2015) and $P$. nicotianae (Bittner and Mila 2014). The effects of fungicide redistribution by water on fungal plant pathogens have previously been shown to be highly dependent on intrinsic toxicity of the compounds (Hislop and Cox 1970). Indeed, the high intrinsic activity of oxathiapiprolin is reflected in the low field dose rates, which at 12 to $30 \mathrm{~g}$ of active ingredient per hectare is substantially lower than that of current oomycete fungicides.

Although all the oxathiapiprolin-based fungicides evaluated here delivered an equal dose of the active ingredient, significant differences were observed among formulation types in postinoculation effects on disease development. In the studies in which formulation products were compared, no differences were observed when the fungicides were applied preventively. However, in postinoculation studies, the OD formulation was significantly more effective than the WG formulation, whereas the SE formulation was equivalent to the WG formulation. The SE formulation contained also famoxadone (a quinone outside inhibitor fungicide), whereas the WG formulation contained also mancozeb (a multisite); however, neither of these active ingredients are known to have curative activity on oomycete fungi (Andrieu et al. 2001; Gullino et al. 2010). Therefore, it is reasonable to conclude that the curative effects observed for these two formulations are coming from oxathiapiprolin alone. Formulation type and adjuvants can significantly impact the uptake of fungicides by plant tissue (Klittich 2014; Zelená and Veverka 2007). In contrast to the dry WG formulation, oxathiapiprolin in the OD and SE formulations is suspended in an oil phase, which may impact movement through the cuticle, but this aspect requires further investigation.
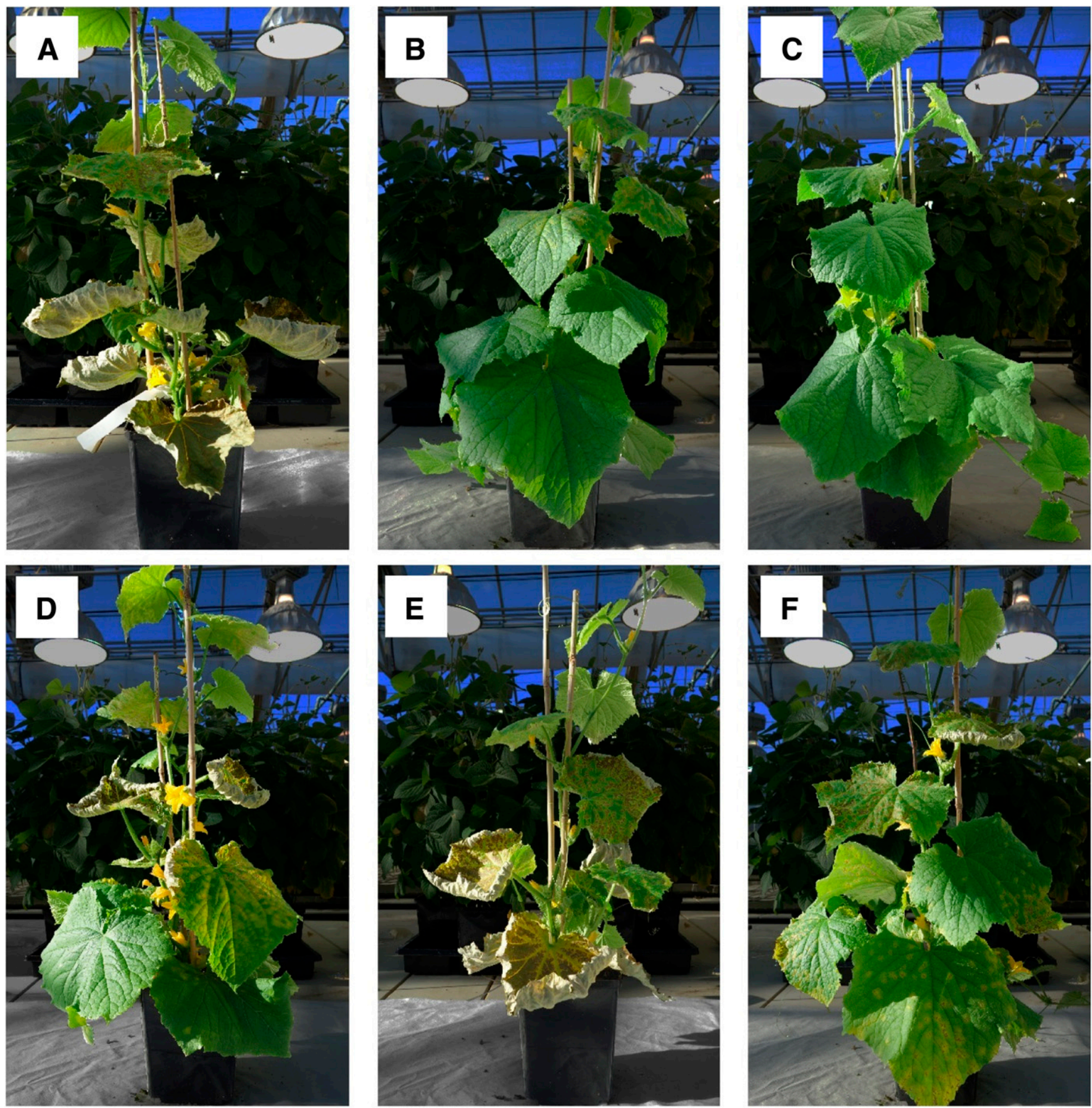

Fig. 5. Effects of oxathiapiprolin-based fungicides and commercial standards on protection of new growth from cucumber downy mildew: A, untreated check; B, oxathiapiprolin + famoxadone; C, oxathiapiprolin + mancozeb; D, fluopicolide + propamocarb; E, mandipropamid; and F, mefenoxam + mancozeb. 
The performance of fungicide products in the field ultimately depends among other factors on the physical-chemical properties, intrinsic activity, and disease control attributes of the active ingredient(s) as modified by product formulation. This study provides useful information on the attributes of oxathiapiprolin-based fungicides critical to understanding the best usage of these products for management of cucurbit downy mildew. Taken together, the results from this work indicate that oxathiapiprolin-based fungicide products will provide growers with a new and highly effective tool for management of cucurbit down mildew that protects new growth and allows for flexibility in fungicide application timing. As such, oxathiapiprolin-based products can be included in practical spray programs with other fungicides, thereby contributing to the management of fungicide resistance in $P$. cubensis.

\section{Literature Cited}

Adams, M. L., Ojiambo, P. S., Thornton, A. C., and McIntyre, J. R. 2013. Evaluation of fungicides for control of downy mildew on cucumber, Sampson County 2012. Plant. Dis. Manag. Rep. 7:V067.

Ando, K., and Grumet, R. 2006. Evaluation of altered cucumber plant architecture as a means to reduce Phytophthora capsici disease incidence on cucumber fruit. J. Am. Soc. Hortic. Sci. 131:491-498.

Andrieu, N., Jaworska, G., Genet, J. L., and Bompeix, G. 2001. Biological mode of action of famoxadone on Plasmopara viticola and Phytophthora infestans. Crop Prot. 20:253-260.

Bittner, R., and Mila, A. 2014. In vitro studies of a novel fungicide against the black shank pathogen, Phytophthora nicotianae. Phytopathology 104:S3-S15.

Blum, M., Waldner, M., Olaya, G., Cohen, Y., Gisi, U., and Sierotzki, H. 2011. Resistance mechanism to carboxylic acid amide fungicides in the cucurbit downy mildew pathogen Pseudoperonospora cubensis. Pest Manag. Sci. 67: 1211-1214.

Call, A. D., Criswell, A. D., Wehner, T. C., Ando, K., and Grumet, R. 2012. Resistance of cucumber cultivars to a new strain of cucurbit downy mildew. HortScience 47:171-178

Cespedes-Sanchez, M. C., Naegele, R. P., Kousik, C. S., and Hausbeck, M. K. 2015. Field response of cucurbit hosts to Pseudoperonospora cubensis in Michigan. Plant Dis. 99:676-682.

Cohen, Y. 2015. The novel oomycide oxathiapiprolin inhibits all stages in the asexual life cycle of Pseudoperonospora cubensis - causal agent of cucurbit downy mildew. PLoS One 10:e 0140015.

Cohen, Y., Meron, I., Mor, N., and Zuriel, S. 2003. A new pathotype of Pseudoperonospora cubensis causing downy mildew in cucurbits in Israel. Phytoparasitica 31:458-466.

Cohen, Y., Van den Langenberg, K. M., Wehner, T. C., Ojiambo, P. S., Hausbeck, M., Quesada-Ocampo, L. M., Lebeda, A., Sierotzki, H., and Gisi, U. 2015. Resurgence of Pseudoperonospora cubensis: The causal agent of cucurbit downy mildew. Phytopathology 105:998-1012.

Colucci, S. J., and Holmes, G. J. 2007. Fungicide insensitivity and pathotype determination of Pseudoperonospora cubensis, causal agent of cucurbit downy mildew. Phytopathology 97:S24.

Colucci, S. J., Thornton, A. C., Adams, M. L., and Holmes, G. J. 2008. Evaluation of fungicides for control of downy mildew of cucumber. Plant. Dis. Manag. Rep. 2:V043.

Gevens, A. J., and Hausbeck, M. K. 2006. Control of downy mildew of cucumbers with fungicides, 2005.Fungic. Nematicide Tests 61:V062.

Gullino, M. L., Tinivella, F., Garibaldi, A., Kemmitt, G., Bacci, L., and Sheppard, B. 2010. Mancozeb, past, present, and future. Plant Dis. 94:1076-1087.

Hausbeck, M. K., and Cortright, B. D. 2009. Evaluation of fungicides for control of downy mildew of pickling cucumber. Plant. Dis. Manag. Rep. 3:V112.

Heaney, S. P., Hall, A. A., Davies, S. A., and Olaya, G. 2000. Resistance to fungicides in the QoI-STAR cross resistance group: Current perspectives. Pages 755-762 in: The British Crop Protection Council Conference: Pests and Diseases, Brighton, U.K.

Hislop, E. C., and Cox, T. W. 1970. Local redistribution of fungicides on leaves by water. Ann. Appl. Biol. 66:89-101.

Holmes, G., Wehner, T., and Thornton, A. 2006. An old enemy re-emerges. Am. Veg. Grower 2:14-15.

Holmes, G. J., Main, C. E., and Keever, Z. T., III. 2004. Cucurbit downy mildew: A unique pathosystem for disease forecasting. Pages 69-80 in: Advances in Downy Mildew Research, Vol. 2.P. T. N. Spencer-Phillips and M. Jeger, eds.Kluwer Academic Publishers, Dordrecht, the Netherlands.

Holmes, G. J., Ojiambo, P. S., Hausbeck, M. K., Quesada-Ocampo, L., and Keinath, A. P. 2015. Resurgence of cucurbit downy mildew in the United States: A watershed event for research and extension. Plant Dis. 99:428-441.
Hübschová, J., and Lebeda, A. 2010. Fungicide effectiveness on Czech populations of Pseudoperonospora cubensis. Acta Hortic. 871:458-464.

Ishii, H., Fraaije, B. A., Sugiyama, T., Noguchi, K., Nishimura, K., Takeda, T., Amano, T., and Hollomon, D. W. 2001. Occurrence and molecular characteristics of strobilurin resistance in cucumber powdery mildew and downy mildew. Phytopathology 91:1166-1171.

Jacob, F., and Neumann, S. 1987. Principles of uptake and systemic transport of fungicides within the plant. Pages 13-29 in: Modern Selective FungicidesProperties, Applications, Mechanisms of Action. H. Lyr, ed. Longman Scientific and Technical, Harlow, U.K

Ji, P., and Csinos, A. S. 2015. Effect of oxathiapiprolin on asexual life stages of Phytophthora capsici and disease development on vegetables. Ann. Appl Biol. 166:229-235

Keinath, A. P., DuBose, V. B., and Lassiter, A. W. 2008. Evaluation of fungicides to manage downy mildew on pickling cucumber in Charleston, South Carolina. Plant. Dis. Manag. Rep. 2:V024.

Kennelly, M. M., Gadoury, D. M., Wilcox, W. F., and Seem, R. C. 2007. Vapor activity and systemic movement of mefenoxam control grapevine downy mildew. Plant Dis. 91:1260-1264.

Kerkenaar, A., and Sijpesteijn, A. K. 1981. Antifungal activity of metalaxyl and furalaxyl. Pestic. Biochem. Physiol. 15:71-78.

Klittich, C. J. R. 2014. Fungicide mobility and the influence of physical properties. Pages 95-109 in: Retention, Uptake, and Translocation of Agrochemicals in Plants. K. Myung, N. M. Satchivi, and C. K. Kingston, eds. ACS Symposium Series, Vol. 1171. American Chemical Society, Washington, DC.

Lebeda, A., and Cohen, Y. 2011. Cucurbit downy mildew (Pseudoperonospora cubensis) biology, ecology, epidemiology, host-pathogen interaction and control. Eur. J. Plant Pathol. 129:157-192.

Lebeda, A., and Urban, J. 2007. Temporal changes in pathogenicity and fungicide resistance in Pseudoperonospora cubensis populations. Acta Hortic. 731: 327-336.

Michereff, S. J., Noronha, M. A., Lima, G. S. A., Albert, I. C. L., Melo, E. A., and Gusmão, L. O. 2009. Diagrammatic scale to assess downy mildew severity in melon. Hortic. Bras. 27:76-79.

Neufeld, K. N., and Ojiambo, P. S. 2012. Interactive effects of temperature and leaf wetness duration on sporangia germination and infection of cucurbit hosts by Pseudoperonospora cubensis. Plant Dis. 96:345-353.

Ojiambo, P. S., and Holmes, G. J. 2011. Spatiotemporal spread of cucurbit downy mildew in the eastern United States. Phytopathology 101:451-461.

Ojiambo, P. S., Paul, P. A., and Holmes, G. J. 2010. A quantitative review of fungicide efficacy for managing downy mildew in cucurbits. Phytopathology 100:1066-1076

Palti, J., and Cohen, Y. 1980. Downy mildew of cucurbits (Pseudoperonospora cubensis): The fungus and its hosts, distribution, epidemiology and control. Phytoparasitica 8:109-147.

Pasteris, R. J., Hanagan, M. A., Bisaha, J. J., Finkelstein, B. L., Hoffman, L. E. Gregory, V., Andreassi, J. L., Sweigard, J. A., Klyashchitsky, B. A., Henry, Y. T., and Berger, R. A. 2016. Discovery of oxathiapiprolin, a new oomycete fungicide that targets an oxysterol binding protein. Bioorg. Med. Chem. 24: 354-361

Pavelková, J., Lebeda, A., and Sedlakova, B. 2014. Efficacy of fosetyl-Al, propamocarb, dimethomorph, cymoxanil, metalaxyl and metalaxyl-M in Czech Pseudoperonospora cubensis populations during the years 2005 through 2010. Crop Prot. 60:9-19.

Reuveni, M., Eyal, H., and Cohen, Y. 1980. Development of resistance to metalaxyl in Pseudoperonospora cubensis. Plant Dis. 64:1108-1109.

Savory, E. A., Gramke, L. L., Quesada-Ocampo, L. M., Varbanova, M., Hausbeck, M. K., and Day, B. 2011. The cucurbit downy mildew pathogen Pseudoperonospora cubensis. Mol. Plant Pathol. 12:217-226.

Sweigard, J. A., Andreassi, J., Pember, S., Gutteridge, S., Pasteris, R. J., Hanagan, M. A., Carroll, A., Sopa, J., and Nesnow, D. 2014. Discovery of the target site of oxathiapiprolin (DuPont Zorvec disease control). 13th IUPAC Congress of Pesticide Chemistry, San Francisco, CA, abstract Agro 911.

Thomas, A., Neufeld, K. N., Seebold, K. W., Braun, C. A., Schwarz, M. R., and Ojiambo, P. S. 2018. Resistance to fluopicolide and propamocarb and baseline sensitivity to ethaboxam among isolates of Pseudoperonospora cubensis from the eastern United States. Plant Dis. 102:1619-1626.

Thomas, C. E. 1996. Downy mildew. Pages: 25-27 in: Compendium of Cucurbit Diseases. T. A. Zitter, D. L. Hopkins, and C. E.Thomas, eds. American Phytopathological Society, St. Paul, MN.

Walters, S. A., and Wehner, T. C. 1994. Evaluation of the U.S. cucumber germplasm collection for early flowering. Plant Breed. 112:234-238.

Zelená, V., and Veverka, K. 2007. Effect of surfactants and liquid fertilisers on transcuticular penetration of fungicides. Plant Prot. Sci. 43:151-156.

Zhu, S. S., Liu, X. L., Wang, Y., Wu, X. H., Liu, P. F., Li, J. Q., Yuan, S. K., and Si, N. G. 2007. Resistance of Pseudoperonospora cubensis to flumorph on cucumber in plastic houses. Plant Pathol. 56:967-975. 